\title{
,УДК 378.14.015.62
}

\section{Гуржій Андрій Миколайович}

доктор технічних наук, професор, дійсний член НАПН України

НАПН України, м. Київ, Україна

ORCID ID 0000-0002-2797-5831

gurzhij.andrij@gmail.com

\section{Бахмат Наталія Валеріївна}

доктор педагогічних наук, професор, професорка кафедри теорії та методики початкової освіти

Кам'янець-Подільський національний університет імені Івана Огієнка, м. Кам'янець-Подільський, Україна

ORCID ID 0000-0001-6248-8468

bahger.teacher@gmail.com

\author{
Зайчук Валентин Олександрович \\ кандидат педагогічних наук, професор, академік НАПН України \\ НАПН України, м. Київ, Україна \\ ORCID ID 0000-0002-8895-1569 \\ zaichuk@narada.gov.ua
}

\section{Карташова Любов Андріївна}

доктор педагогічних наук, професор,

заступниця директора 3 дистанційного навчання

Центральний інститут післядипломної освіти УМО НАПН України, м. Київ, Україна

ORCID ID 0000-0002-1270-4158

lkartashova@ua.fm

\section{Розман Ірина Іллівна}

кандидат педагогічних наук, доцентка кафедри філології та соціальних комунікацій

Мукачівський державний університет, м Мукачево, Україна

ORCID ID 0000-0002-4951-0074

rozmanii@ukr.net

\section{Сорочан Тамара Михайлівна}

доктор педагогічних наук, професор, професорка кафедри філософії і освіти дорослих

Університет менеджменту освіти НАПН України, м. Київ, Україна

ORCID ID 0000-0002-4704-2385

anprof@ukr.net

\section{ОРГАНІЗАЦІЙНІ ЗАСАДИ ФОРМУВАННЯ ЦИФРОВОЇ ІНФРАСТРУКТУРИ ОСВІТИ І ПЕДАГОГІЧНОЇ НАУКИ В УКРАЇНІ (КІНЕЦЬ 80-Х РР. ХХ СТОЛІТТЯ-ПОЧАТОК ХХІ СТОЛІТТЯ)}

\begin{abstract}
Анотація. У статті розглянуто передумови, динаміку, тенденції, інституційну базу розвитку сучасної педагогічної біографії в Україні. Підкреслено, що на кінець 80-х років XX ст. початок XXI ст. припадає зростання інтересу науковців до педагогічної біографії, а історіографія в цьому аспекті набуває актуальності. Акцентовано увагу на значному обсязі та різноманітності історіографічних матеріалів. За результатами аналітичного огляду встановлено, що досліджувані матеріали, представлені в трьох категоріях, презентують спробу персоніфікації розвитку української педагогічної думки та вивчення діяльності педагогічної спільноти України за межами держави. Доведено актуальність наукового дослідження життя і спадщини видатних українських педагогів, які визначали освітню політику та розвивали наукову педагогічну думку в різні історичні періоди державотворення. Зазначено, що бібліографія, і як галузевий ресурс, i як пошукова інфраструктура, зумовлює доцільність створення цифрової бібліографії, інших цифрових ресурсів як інноваційних інструментів пошуку біографічних відомостей про видатних українських педагогів та вчених світового рівня. Ефективність зазначеного підтверджена потужною системою біографістики зарубіжних країн, представленою в сучасному цифровому середовищі - Інтернеті. Підкреслено, що в більшості випадків автори наукових досліджень обмежуються стислим поданням біографії видатних педагогів відповідно до
\end{abstract}


предмету конкретного дослідження. Уточнено, що в сучасній українській історикопедагогічній науці сформувався окремий міждисциплінарний дослідницькоперсоніфікований напрям - педагогічна біографістика, яка в силу невпинного зростання масиву наукової, навчальної, науково-популярної, довідкової літератури та інших інформаційних джерел про педагогічні персоналії, безсумнівно, потребує відтворення, зберігання і використання саме в цифровому форматі. Отже, на часі персоніфікація історії освіти і педагогічної думки в Україні в інноваційному форматі цифрової інфраструктури, що не лише забезпечить сучасні форми партнерства i співробітництва вітчизняних дослідників персоналій із світовою спільнотою науковців, але й сприятиме подальшому науковому розвитку української педагогічної біографістики.

Ключові слова: педагогічна думка; педагогічна біографістика, історія, просопографія; бібліографія, персоніфікація; ідентифікація; ресурс; інформатизація; цифрові технології, цифрова інфраструктура, цифровізація.

\section{1. ВСТУП}

Постановка проблеми. Розгляд передумов, динаміки, тенденцій, інституційної бази, інших аспектів розвитку сучасної педагогічної біографістики в Україні наприкінці 80-х pp. XX ст. - початку XXI ст. становить підгрунтя для предметного осмислення відповідної історіографії. Зважаючи на накопичені історіографією значні обсяги джерельних матеріалів різного виду та відповідно до результатів їх аналітичного огляду, виокремлено три категорії розподілу, що охоплюють праці, у яких здійснюється персоніфікація розвитку української педагогічної думки та студії про педагогічні персоналії України і зарубіжжя. Виходячи з того, що бібліографія і як відповідний галузевий ресурс, і як пошукова інфраструктура, зумовлює потребу використання цифрової бібліографії, прогнозуємо актуальність трансформації бібліографії персон історії освіти і педагогічної думки в Україні в інноваційну цифрову інфраструктуру державного та всесвітнього рівнів відповідно до зростаючої цифровізації (діджиталізації) суспільства в цілому, педагогічної біографістики зокрема.

Аналіз останніх досліджень і публікацій. Сутність категорій базових термінів біографістики досліджено й визначено вченими-педагогами: Н. Дічек, О. Сухомлинською, В. Чишко, Н. Попик; ученими-філософами: О. Валевським, I. Голубовичем, В. Менжулінти ін.; ученими-психологами: Б. Ананьєвим, Н. Логіновою, С. Рубінштейном та ін.; ученими-істориками: І. Бєлєнькою, Л. Рєпіною, П. Попик, В. Чишко, О. Ясь та ін.

Актуальність дослідження проблеми формування i розвитку педагогічної біографістики в Україні в другій половині XX - на початку XXI ст. обумовлена низкою соціокультурних, освітніх, педагогічних, наукових чинників.

Теоретична основа дослідження грунтується на науковому доробку та провідних ідеях І. Аносова, Л. Артамошкіна, М. Берулава, Б. Бім-Бада, А. Закірова, І. Зязюна, Н. Іпполітова, М. Кагана, В. Кузьменка, В. Курила, В. Кремена, В. Лаппо, О. Новікоав, В. Онищенка, А. Сбруєва, С. Сисоєва, Н. Скотної, Н. Ткачова, С. Рубіштейна та ін.

Практичне значення результатів дослідження полягає в можливості використання представленого в ньому фактографічного матеріалу, теоретико-методологічних положень і висновків, фахових і міжгалузевих наукових студій і джерельних матеріалів різного виду в професійній підготовці майбутніх педагогів, зокрема у викладанні дисциплін гуманітарного й психолого-педагогічного циклів: «Педагогіка», «Історія педагогіки», «Методологія наукового дослідження», «Теорія і методика виховання».

Осмислення і використання доробку науковців суспільно-історичного напрямку персонології, представленого в дослідженнях кінця XX ст., корисне з точки зору їх орієнтованості на висвітлення життєдіяльності персоналій цього і попередніх періодів 
як потенційних носіїв цінного емпіричного i теоретичного матеріалу в царині психології особистості, розвитку освіти, педагогічного пошуку тощо.

Зважаючи на складність і багатогранність персонології, іiі феномен розглядається як інтегральний напрям психології особистості, що грунтується на міждисциплінарних дослідженнях людини в іiі гносеологічних, онтологічних і культурних вимірах. Засновником персонології визнається американський психолог Г. Мюррей (1893 1988). Відтак вона отримала розвиток у другій половині XX ст. у західних країнах, а в 90-х pp. ХХ ст. - і на пострадянському просторі.

Отже, аналітичний огляд наукових праць дослідників дозволив виявити, що таке широко вживане базове поняття історико-педагогічної науки, як «педагогічна думка» фактично ще не визначалося предметом спеціального всебічного термінологічного аналізу. Про це також свідчить відсутність цього поняття в академічних довідникових виданнях [1], [2], [3], [4]. У науковій і навчальній літературі воно вживається досить довільно, з прив'язкою до певного періоду (епохи), країни, теми дослідження тощо. У спеціальних педагогічних студіях науковці, як правило, обмежуються стислим трактуванням поняття відповідно до предмету власного наукового дослідження.

Мета статті: обгрунтувати особливості розроблення інноваційного формату персоніфікації історії освіти і педагогічної думки в Україні на основі цифрової інфраструктури.

\section{2. МЕТОДИКА ДОСЛІДЖЕННЯ}

У ході дослідження особистим внеском А. Гуржія $\epsilon$ уточнення та опис зарубіжного досвіду збирання бібліографій відомих постатей - платформ ушанування пам'яті видатних людей, виокремлення потреби формування цифрової інфраструктури в Україні; здійснення огляду відповідних зарубіжних цифрових платформ; проведення та опис системної предметно-пошукової роботи зарубіжного досвіду стосовно педагогічної біографістики, виявлення фактів появи в 2008-2009 рр. практики підготовки й представлення бібліотечними установами календарів знаменних i пам'ятних дат на вебсайтах.

I. Розман вивчено та проаналізовано праці дослідників у галузі української історико-педагогічної науки; обгрунтовано проблему персоналізації української педагогічної думки на основі наукового аналізу ряду праць науково-дослідницького, дидактичного, довідкового, просвітницького спрямування; обгрунтовано потребу пошуку інноваційних підходів до висвітлення історії розвитку національної освіти і педагогічної думки.

Н. Бахмат проаналізовано зарубіжні дослідження щодо персоніфікації історії освіти і педагогічної думки; доведено, що оцифровування інформації про відомі постаті - їх діяльність і життя - зумовлене інформаційною потребою освітніх i наукових закладів та установ; висвітлено принципові підходи зарубіжних учених до розроблення систем бібліографії та біографістики в умовах сучасного динамічного цифрового середовища.

Л. Карташовою здійснено аналітичний огляд становлення та розвитку української педагогічної бібліографії за доби державної незалежності (90-ті рр. XX - початок XXI ст.), висвітлення відповідної інформації в Інтернеті; обгрунтовано потребу оновлення підходів персоніфікації з урахуванням можливостей цифрових технологій; уточнено можливості створення галузевих бібліографічних ресурсів на цифровій основі; узагальнено принципові положення щодо створення світових інформаційноосвітніх ресурсів; виявлено перспективні шляхи презентації освітньо-педагогічних феноменів окремих історичних періодів, генерацій педагогів і науковців. 
Т. Сорочан проаналізовано базові методичні підходи і прийоми з точки зору їх застосування в ході вивчення окремих генерацій, груп, категорій та інших сегментів педагогічної думки й персоніфікації освітнього процесу України; акцентовано й описано статус пам'ятних календарів як різновиду навчально-методичного забезпечення, особливого формату біобібліографії, що сприяє розвиткові педагогічної біографістики.

В. Зайчуком проведено відповідні науковому пошуку спеціальні розвідки, описано результати розвитку педагогічної бібліографії України в період 30-х pp. - 80-ті pp. XX ст., проаналізовано основні аспекти історіографії педагогічної біографістики в хронологічному, регіональному та інших вимірах.

\section{3. РЕЗУЛЬТАТИ ДОСЛІДЖЕННЯ}

Доробок українських і зарубіжних учених надає важливі методологічні орієнтири для розуміння суті феномену «педагогічна думка». Так, О. Сухомлинська відзначає, що національна педагогічна думка - широке поняття духовної, культурної сфери, до якої, окрім педагогіки, належать і філософія, і релігія, й ідеологія, мораль, етика та низка інших складників. Вона завжди персоніфікована, бо віддзеркалює особистість носія 3 притаманними йому поглядами, віруваннями, уподобаннями. У центрі уваги педагогічної думки перебувають наукове пізнання й онтологічний пошук знаходження, опис, систематизація педагогічних фактів, їхнє оцінювання [5, с. 3].

Дослідницею Т. Усатенко розкрито важливий українознавчий аспект педагогічної думки як множинного, багатогранного явища, яке доцільно аналізувати крізь призму головних педагогічних теорій, змісту і парадигм освіти, типів наукового знання, українознавчих орієнтацій. Вона доводить, що педагогічна думка становить окремий напрям історико-педагогічних досліджень, має власний науково-пошуковий простір, об'єкт, предмет дослідження, дидактичні основи тощо. Ї̈ї бурхливий розвиток в історико-педагогічному процесі XIX - XX ст. зумовлений суспільно-економічними й політичними чинниками, провідну роль у цьому процесі відіграли педагогічні ідеї і течії [6, с. 13-15].

Методологічний аспект різниці між поняттями «педагогічна думка» та «історіографія» пояснюється І. Стражніковою. На думку дослідниці, перше 3 них є «ширшим», бо охоплює коло феноменів духовної культури (філософія, ідеологія, мораль, етика) та разом 3 науково-педагогічними знаннями спирається на народну педагогіку. Спільним для них $\epsilon$ спрямованість на персоналізацію освітньопедагогічного процесу, адже вони відображають погляди авторів, детерміновані різними особистими й суспільними чинниками [7, с. 41-44].

В українській історико-педагогічній науці на сьогодні ще не напрацьовано спеціального методологічного інструментарію для дослідження розвитку педагогічної думки. За таких умов апелюємо до науково-теоретичного досвіду просопографії міждисциплінарної галузі знань, яка визначає принципи, засади, методи вивчення колективних біографій певних груп людей, об'єднаних за спільними ознаками. Виходимо з позиції, згідно з якою здійснення просопографічного опису має (може) містити виявлення та зіставлення компонентів, що стосуються:

a) шляхів і чинників їх формування (родинне і соціальне середовище, сфери діяльності, місця перебування тощо);

б) особистісні характеристики (походження, психофізіологічні стани, стосунки 3 оточенням, приватне життя та ін.);

в) внутрішній особистісний світ, зокрема ставлення до культурно-наукового простору, громадського життя; 
г) шляхи самореалізації особистості тощо.

Аналітичний огляд напрацьованих ученими (М. Петрова [8]; I. Петровська [9]; I. Старовойтенко [10]; Ю. Юмашева [11] та ін.) методичних підходів і прийомів та їх урахування є важливим аспектом для вивчення окремих генерацій, груп, категорій, інших сегментів педагогічної думки та персоніфікації освітнього процесу України. Важливо підкреслити, що виявлені характеристики передусім є необхідними для осмислення спільного й особистісного в колі педагогічних ідей і поглядів як окремих персон, так і груп.

Для розв'язання цього завдання доцільним вважаємо запропонований у роботах В. Курила критеріально-комплексний підхід, що передбачає використання комплексу критеріїв, які відображають сукупність суттєвих характеристик педагогічної думки та забезпечують багатовимірний аналіз і оцінювання поточних результатів [12, с. 6-8]. У нашій інтерпретації вони орієнтують на з'ясування і врахування:

a) методологічних засад наукових студій та їх тематичної спрямованості;

б) механізмів формування дослідницької проблематики;

в) особливостей процедури педагогічних пошуків;

г) рівня розвитку науково-педагогічної комунікації;

г) новизни, оригінальності результатів наукових студій;

д) взаємозв'язку і відповідності внутрішньої логіки розвитку педагогічної науки, педагогічної думки й освітньої практики;

є) рівня підготовки наукових досліджень і характеру наукової продукції:

ж) особистісних характеристик носіїв педагогічної думки.

Перед з'ясуванням проблеми персоніфікації історії розвитку освіти і педагогічної думки в Україні відзначимо важливу тенденцію, що характеризує процес нагромадження присвячених їй студій. Зокрема виявлено, що з середини 90-х рр. XX ст. потік студій набув стрімкого зростання - як наслідок впливу піднесення педагогічної біографістики. Тобто повернення 3 небуття персоналій українських педагогів та введення до наукового обігу й освітнього процесу персоналій діячів зарубіжної педагогіки сприяло розширенню загального кола відомостей, що подавались у виданнях різного виду. Попри об'єктивно обумовлену суб'єктивність цього процесу, вимальовувалась загальна картина, що призвела до формування вітчизняного пантеону постатей, які забезпечили розвиток української і зарубіжної освіти та педагогічної думки.

Структуру педагогічної науки презентують академічні довідникові й енциклопедичні видання, що, згідно з думкою укладачів, подають персоналії діячів, які зробили найвагоміший внесок у розвиток української і світової освіти й педагогіки. Об'єктами аналізу нами обрано два авторитетні видання: «Український педагогічний словник» (1997 р.) С. Гончаренка [4] та «Енциклопедію освіти» (2008 р.) за редакцією В. Кременя [3], у яких відображаються пострадянська та нова проєвропейська освітньонаукові парадигми.

В «Українському педагогічному словнику», згідно 3 нашими підрахунками, уміщено близько 765 статей про персоналії, які, за баченням автора, досягли вагомих здобутків у «галузях освіти й педагогічної науки» та заслуговують на «позитивне оцінювання» своєї діяльності громадськістю [4, с. 8]. Частина 3 них присвячена українським діячам, що класифіковані за певними критеріями (дійсні члени і членикореспонденти АПН України, українські педагоги, обрані до АПН СРСР та відзначені званнями Героя Соціалістичної Праці, народного учителя, заслуженого діяча освіти; автори педагогічних концепцій і підручників; керівники закладів освіти; учителіноватори). Інша частина статей презентує імена зарубіжних учених-педагогів, 
представників різних галузей знань та державних і культурних діячів, які зробили вагомий внесок у розвиток і реформування освіти.

В українській педагогічній науці надто складно знайти аналогічне видання, яке б систематизувало інформацію про таку велику кількість персоналій. У структурному плані статті реферованого словника складаються з блоків, що розкривають біографічні дані педагогів (місце і дати народження та смерті; етнічна приналежність); відомості про фах, вчені ступені і звання, професійну діяльність; перелік основних наукових доробок; визначення сутності особистої педагогічної концепції або наукового досвіду тощо.

Укладачі «Енциклопедії освіти» у відборі персоналій спирались на методологічну позицію, згідно з якою пріоритетами діяльності і творчості презентованих осіб мали бути засади демократії і гуманізму, плюралізму трактування наукових ідей і концепцій тощо. Відповідно до наших підрахунків, у виданні вміщено близько 130 статей про діячів, які, за думкою авторського колективу, найбільше спричинилися до розвитку теорії і практики вітчизняної і зарубіжної освіти [3]. Це видання увиразнює притаманну носіям педагогічної думки, починаючи від доби Античності й до сьогодення, інтелектуальну та діяльнісну ознаку, що полягає в інтегрування ними ідей, досвіду, інновацій, нагромаджених у різних галузях знань і суспільних сферах. Наукова цінність зібраних в енциклопедії матеріалів полягає в концептуалізації розроблених персоналіями теоретичних ідей і поглядів, ініційованих ними освітніх реформ, апробованих освітніх технологій тощо.

Сучасні науковці акцентують увагу на кардинальних зрушеннях у царині педагогічної бібліографії, що відбулися за доби державної незалежності. Проте іiі формування в Україні має глибші традиції, адже попри певну невиразність цього процесу можемо виокремити два основні періоди в його розвитку. Перший охоплює середину 30-х pp. - 80-ті pp. XX ст. і визначається появою праці Є. Пеленського та спробами укладання бібліографії відомих українських педагогів радянської доби. Другий період припадає на 90-ті pp. XX ст. - початок XXI ст., коли за умов повернення 3 небуття педагогічних імен, оприлюднення оновлених персоналій та завдяки використанню інноваційних комп'ютерних технологій розпочалося створення галузевого бібліографічного ресурсу на принципово новій основі.

Зважаючи на окреслені науково-теоретичні i конкретно-тематичні позиції, з'ясування проблеми формування й розвитку педагогічної бібліографії в Україні здійснюємо за логікою переходу від загального до конкретного. Ідеться про те, що саме вона $\epsilon$ складником загальнонаціонального бібліографічного поля, яке цілковито виявляється у метабібліографії. Поточний облік бібліографічних посібників в Україні започаткувала поява в 1924 р. «Літопису українського друку»; у 1926-1928 рр. виходив щорічник «Бібліографічна робота на Радянській Україні». Неперервного системного характеру цей процес набуває лише з 1971 р. завдяки виданню щорічника «Бібліотекознавство і бібліографія Української РСР»; продовженням стало видання «Бібліотекознавство і бібліографія України» (до 2007 р.), 32009 р. започатковано бібліографічний покажчик «Метабібліографія України». На такому тлі розвивалася галузева метабібліографія [13].

На початку XXI ст. увиразнилися основні контури персоналізації тисячолітньої історії розвитку української педагогічної думки. Винятково важлива роль у цьому відводиться знаковому двотомнику «Українська педагогіка в персоналіях» (2005р.), укладеному колективом авторитетних науковців за редакцією О. Сухомлинської. Видання є вагомим внеском у розроблення науково-методологічних засад вивчення педагогічної думки. Йдеться про предметне з'ясування аспектів, що стосуються: а) принципів добору персоналій (представники минулого, які зробили «вагомий, 
помітний або певний» внесок у вітчизняну педагогічну науку та/або були вилучені 3 історико-педагогічного процесу з ідейно-політичних і класово-партійних міркувань); б) зосередження уваги на постатях, які своєю діяльністю, світоглядною позицією вплинули на сучасників та забезпечили подальший розвиток науки і освіти; в) наголосу на ідею соборності України, яка через творчу біографію дозволяє відтворити «єдиний педагогічний простір»; г) нового прочитання життєдіяльності педагогів завдяки переосмисленню їхньої спадщини та використання маловідомих фактів тощо [5].

Відповідно до методологічно обгрунтованого просторово-часового підходу було позначено три основні періоди, за якими здійснювалась персоналізація розвитку української педагогічної думки:

1) Княжа доба і Козаччина (X - XVIII ст.);

2) педагогіка Просвітництва (XIX ст.);

3) педагоги України в XX ст.

Слід визнати іiі «умовність», адже, згідно з концептуальним задумом, уміщені в праці статті мають скомбінувати життєпис і рефлексії педагогів, i теоретиків i практиків, що здійснювали науково-практичну діяльність за різних суспільнополітичних умов розвитку Російської і Австро-Угорської імперій, а також персоналій українського зарубіжжя, що становлять окреме явище національної педагогічної думки. Це потребувало врахування відмінностей у їх типі мислення, самоідентифікації, самосвідомості, які визначали зміст і напрями дій та наукових інтересів [5].

Статті-нариси реферованого видання побудовані за чіткою схемою, що передбачає наступне: фіксацію біографічних даних персоналії; визначення сутності їі діяльності й громадянської позиції; подачу основних творів діяча та наукових студій про нього тощо. Усього, згідно з нашими підрахунками, у ньому представлено 164 педагогічні персоналії. Їх ідентифікація за окремими періодами й основним соціальним статусом (фахові педагоги, діячі літератури, державні, громадські, церковні діячі, представники різних галузей знань) показана в Таблиці 1.

Таблиия 1

Кількісні показники соціального статусу діячів, представлених у нарисах двотомника «Українська педагогіка в персоналіях» (2005 р.)

\begin{tabular}{|l|c|l|c|}
\hline $\begin{array}{l}\text { Основний } \\
\text { соціальний статус } \\
\text { персоналії }\end{array}$ & $\begin{array}{l}\text { Княжа доба і } \\
\text { Козаччина } \\
\text { (IX-XVIII ст.) }\end{array}$ & $\begin{array}{l}\text { Доба } \\
\text { Просвітництва } \\
\text { XIX ст. }\end{array}$ & $\begin{array}{l}\text { Педагогіка } \\
\text { України XX ст. }\end{array}$ \\
\hline Педагоги & - & 13 & 44 \\
\hline Діячі літератури & 8 & 15 & 8 \\
\hline $\begin{array}{l}\text { Державні і } \\
\text { громадські діячі }\end{array}$ & 3 & 3 & 1 \\
\hline Церковні і діячі & 17 & - & 15 \\
\hline $\begin{array}{l}\text { Представники різних } \\
\text { галузей знань }\end{array}$ & 7 & 17 & 9 \\
\hline
\end{tabular}

Визнаємо умовність критерію «основний соціальний статус», але він певною мірою відображає основну домінуючу ідентифікаційну ознаку, відповідно до якої діяч, передусім, персоніфікується в загальній довідниковій літературі та суспільній свідомості. У розрізі нашого дослідження можна говорити про «подвійну», навіть «множинну» ідентифікацію педагогічних персоналій, адже, приміром, для доби Козаччини більшість церковних діячів (основний соціальний статус) водночас були і письменниками-полемістами, і представниками різних галузей знань тощо.

Попри означені вище та інші умовності, представлені в Таблиці 1, відомості увиразнюють основну тенденцію, згідно з якою педагоги як носії педагогічної думки 
почали виокремлюватися з соціального середовища лише в XIX ст., у XX ст. вже було близько половини діячів, чиє життя і творчість вивчаються з позицій педагогічної біографістики. Водночас доволі високим за цих двох періодів залишався відсоток неохоплених представників різних галузей знань і діячів літератури (чимало з яких у такому розрізі також розмежовуються умовно). Зростання кількості державних i громадських діячів пояснюється інтересом до їх діяльності з реформування системи освіти тощо.

Окрім згаданого видання, проблемі персоналізації української педагогічної думки присвячено низку інших праць науково-дослідницького, дидактичного, довідкового, просвітницького спрямування. 3-поміж них, як приклад, відзначимо три видання: перше - «Літопис педагогічної думки в Україні» (Д. Луцик, Т. Логвиненко, 2000), що став однією з перших спроб представити в систематизованому вигляді життєвий шлях і творчі ідеї відомих діячів різних періодів: Г. Сковороди, О. Духновича, Т. Шевченка, К. Ушинського, Х. Алчевської, Т. Лубенця, I. Франка, С. Русової, Б. Грінченка, М. Грушевського, Лесі Українки, Я. Чепіги, Г. Ващенка, А. Макаренка, В. Сухомлинського, О. Савченко. Друге видання - «Персоналії в історії національної педагогіки»- репрезентує творчість 20 і 22 видатних українських педагогів (2002, 2004) [14], [15]. Доходимо висновку, що при відборі персоналій укладачі намагалися поєднати, з одного боку, «найбільш знакових» для розвитку української культури i науки діячів, до прикладу, Т. Шевченка, М. Грушевського, В. Вернадського, Лесю Українку тощо, внесок яких у розвиток української освіти, педагогіки i просвітництва $\epsilon$ незаперечним. 3 іншого боку, до видання увійшли імена десятків «менш відомих» учених-педагогів, яких визнано творцями оригінальних педагогічних концепцій і дидактичних систем.

Зазначене певною мірою стосується й третього видання - «Нариси 3 історії розвитку педагогічної думки», що, відмежувавши персоналії зарубіжжя, в єдиному просторі «створення національної системи освіти» представило діячів української педагогічної думки (Г. Сковорода, О. Духнович, К. Ушинський, М. Корф, І. Франко та інші) та в такому ж ракурсі 24 діячі, які персоніфікували історію розвитку «вітчизняної педагогіки» XX ст. [16]. Спільним для трьох означених доволі змістовних праць $є$ намагання узагальнити та сконцентровано продемонструвати основні здобутки української педагогічної біографістики кінця XX - початку XXI ст.

Також заслуговує на відзначення інформаційний довідник «Видатні українські педагоги», у якому біографічні відомості про життєвий шлях і творчу діяльність Г. Сковороди, Г. Ващенка, С. Русової, В. Сухомлинського та М. Стельмаховича доповнює добірка стрижневих ідей учених з проблем виховання і розвитку особистості, бібліографія їх основних праць і публікацій про них, а також розроблені й апробовані автором методичні розробки навчальних і виховних заходів, що грунтуються на ідеях педагогів [17]. Такий формат підвищує затребуваність книжки, що може використовуватись у бібліографічно-пошукових, науково-дослідницьких і дидактичних цілях.

Об'єктивно обумовлена зосередженість сучасних науковців i освітян на педагогічних персоналіях XIX - 30-х pp. XX ст. витіснила «повоєнні радянські десятиліття», коли навіть за умов панування тоталітарного режиму продовжувалась самовіддана праця зі збереження й розвитку національних культурно-освітніх цінностей. За таких обставин зростає науково-пізнавальний інтерес до видань на кшталт біографічного збірника «Герої-освітяни і науковці України» [18], що презентує плеяду діячів, які за бойові вчинки та трудові і творчі здобутки були відзначені званнями Герой Радянського Союзу, Герой Соціалістичної Праці, Герой України. Ця меморіальна праця умовно претендує на статус «колективної біографії», адже за 
спільними ознаками відтворює життєвий шлях кількох генерацій діячів та демонструє їх духовний зв'язок. Вона доводить потребу ретельного вивчення життя й здобутків непересічних постатей, що визначають обличчя освіти і педагогіки недавнього минулого.

Важливим аспектом наукових розвідок за проблемою створення цифрової інфраструктури історико-педагогічних досліджень $є$ розуміння самого поняття інфраструктури та адаптації його до наративу персоніфікації наукової думки.

Поняття інфраструктури $€$ базовим для економічної галузі знань і визначає сукупність матеріальних об'єктів, що взаємопов'язані між собою і забезпечують певний рівень комфорту життя. Проте сучасне розуміння сутності i значення інфраструктури поширюється на соціальні науки, зокрема педагогіку. У контексті нашого дослідження цифрову інфраструктуру розуміємо як цифровий комплекс вебпослуг - цифрову платформу, умови якої забезпечують упорядкування, узагальнення i систематизацію значного обсягу інформації, наукових фактів, концепцій, практичних розробок, документів тощо в галузі педагогіки і освіти. Цифрова платформа є інструментом персоналізації, об'єктами якого є біографії вчених, їх праці; вона охоплює методи, форми, технології роботи зі здобувачами освіти, практичний досвід учених, наукові досягнення, відтворені в соціумі.

Аналіз зарубіжних досліджень [19], [20], [21], [22], [23] показав, що для персоніфікації історії освіти й педагогічної думки в розвинутих країнах світу відбувається формування цифрової інфраструктури. Так, в online-режимі можна знайти велику кількість платформ, доступних для дослідників цього напряму. Цікавим $\epsilon$ дослідження [20], у якому зібрання бібліографій відомих постатей називають платформою для вшанування пам'яті видатних людей зі світу науки та зазначається, що «незважаючи на важливу роль для наукового співтовариства, дослідження біографічних статей є обмеженим».

Оцифровуванням Google Books i Open Content Alliance (OCA) здійснено прорив у доступі до цифрових ресурсів, що є надзвичайно важливим для користувачів, однак доступ до ресурсів $є$ дещо обмеженим з технічної точки зору створення придатних аналогів друкованих видань [22].

Сьогодні оцифровування інформації про відомі постаті, їх діяльність і життя визнається освітніми та науковими закладами й установами, оскільки це покращує доступ до основної інформації про відомих людей, збільшує ії використання й актуальність. В Інтернеті існують і активно поповнюються оцифровані колекції бібліографій, зокрема на сайті https://bookauthority.org/ розміщено рекомендовані книги про бізнес, технології та науку, зокрема у вкладці «наукові біографії» викладено найкращі наукові біографічні книги всіх часів [24].

Найбільша у світі американська компанія Amazon $\epsilon$ платформою електронної комерції, яка розміщує оцифровані книги-бестселери біографій освітян [19].

В енциклопедії Нового Світу в галузі біографії представлено список статей [25]. Вибір предметних галузей на цьому ресурсі $є$ загальним орієнтиром та одним 3 багатьох способів знайти статтю. Нова Світова Енциклопедія впорядкована в алфавітному порядку за статтями та пов'язана гіперпосиланнями з однієї статті в іншу. Ресурс також має потужний інструмент для швидкого пошуку статей - біографій відомих педагогів та вчених США за ключовими словами.

На цьому вебсайті можна переглядати статті за алфавітним порядком, вибрати матеріал іншої предметної галузі або натиснути на гіперпосилання, щоб переглянути необхідний матеріал про категорію «Біографія» (рис.1). 


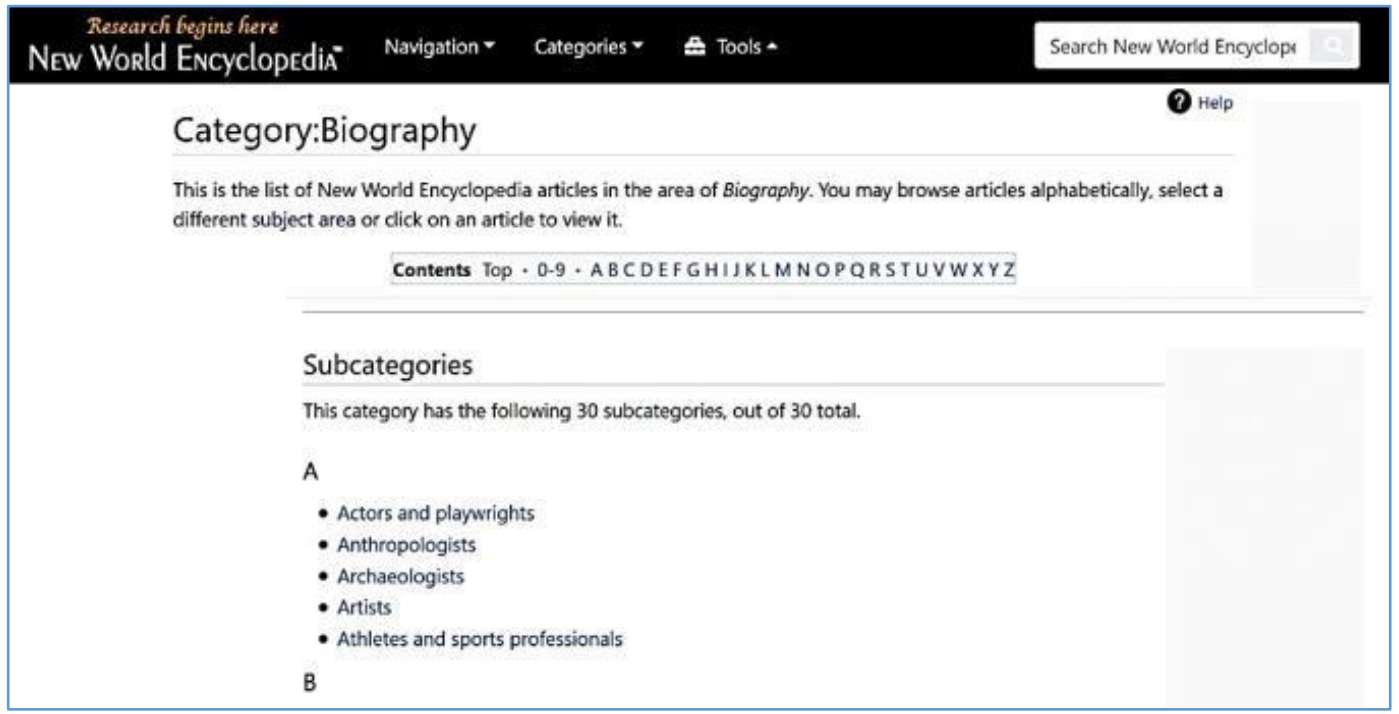

Рис. 1. Категорія «Біографія» Енииклопедії Нового Світу

У цій категорії є 30 підкатегорій, які містять гіперпосилання на персоналії відомих науковців, педагогів, філософів, психологів тощо (рис.2).

\begin{tabular}{|c|c|c|}
\hline \multicolumn{2}{|c|}{$\begin{array}{l}\text { Category: Educators and } \\
\text { Educational theorists }\end{array}$} & 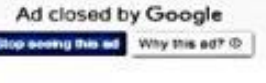 \\
\hline \multicolumn{3}{|c|}{ Pages in category "Educators and Educational theorists" } \\
\hline A & G cont. & P cont. \\
\hline - Alexander Emanuel Agassiz & - Sarah and Angetina Grimwe & - Colestia Susannan Parrish \\
\hline - Louis Rodolphe Agassiz & - Guarino da verona & - Ellzabeth Peabody \\
\hline - Amos Bronson Aveott & $\mathbf{H}$ & - Johann Heinnen Pestatozz \\
\hline B & H & - Laurence $\perp$, Peter \\
\hline - Stephen M Babcock & $\begin{array}{l}\text { : Wuam Torey Harris } \\
\text { Johann Freankh Herbart }\end{array}$ & $\mathbf{R}$ \\
\hline - wiliam Chandier Bapley & - Patty Smith riti & - Carr Rogers \\
\hline - Alexander Bain & - Charies Hamitton Houston & - Harriet Burbank Rogers \\
\hline - Catharine Esther Beecher & - Wineim von Humbolat & - Benjamin Rush \\
\hline $\begin{array}{l}\text { - Susan Blow } \\
\text { : Bernhard Botzano }\end{array}$ & $\mathbf{I}$ & s \\
\hline - Lovis Braile & - Elisabeth Antoinette inwin & - Edouara Seguin \\
\hline - Nucholas M. Butter & - Jean Marc Gaspard Itard & - Rucour Steiner \\
\hline c & $\mathbf{K}$ & $\begin{array}{l}\text { - Gustar steckiey } \\
\text { - whilam stokee }\end{array}$ \\
\hline $\begin{array}{l}\text { - Comentius } \\
\text { Pierre de Coubertin }\end{array}$ & - Maria Kraus-8oenté & (5) \\
\hline - Pierre de coubertin & L & - whiliam Temple \\
\hline D & - Lewis, C.1. & - Tzuetan Todoror \\
\hline - John Dewey & - nur Lotman & - Lonel Triling \\
\hline
\end{tabular}

Рис. 2. Сторінки в категорії «Педагоги та теоретики освіти» Енииклопедї Нового Світу

Сайт Національної біографії Фінляндії [26] є збірником біографій 6500 фінів, починаючи 3 давніх часів, які були підготовлені як один 3 найбільших історичних проєктів для фінського історичного товариства в 1993-2001 роках.

Національна біографія Фінляндії містить не лише приклади життя великих людей країни, а й безліч менш відомих фігур, які були представниками своєї галузі чи декількох з них, вихідців 3 різних верств суспільства в усі періоди його розвитку (рис.3). 


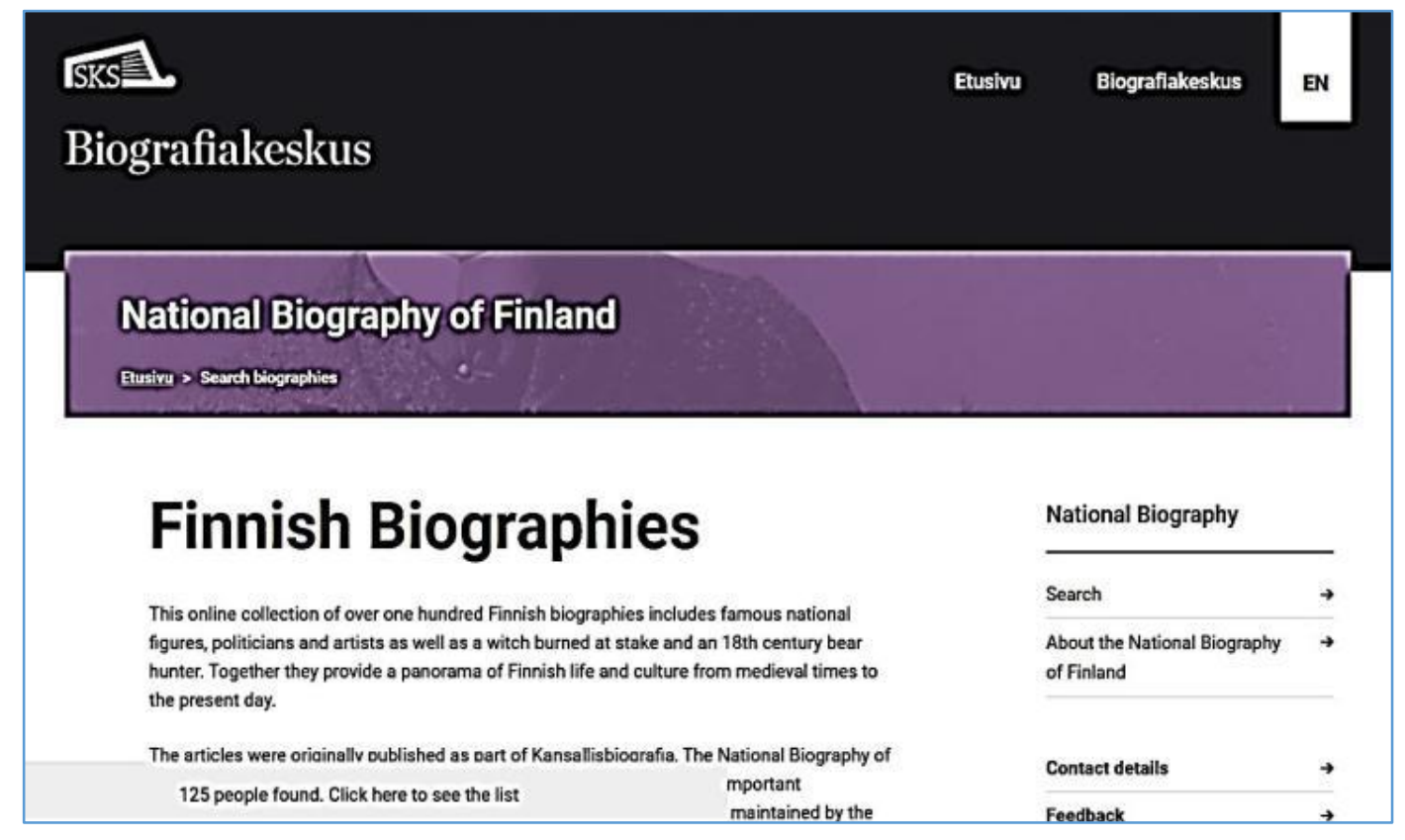

\section{Рис. 3. Головна сторінка Національної біографї Фінляндї}

За основною професією видатні люди представляють такі галузі: правителі, міністри, члени парламенту (13\%), учені, педагоги (14\%), письменники, журналісти, видавці (10\%), державні посадові особи, судді (10\%) тощо.

Національна біографія Фінляндії публікується як у вигляді книги, так і в Інтернеті.

Biography Online була заснована в 2006 році Тейваном Петтінгером як інформація про людей різних історичних епох і сьогодення, їхні права, релігійну толерантність, твори мистецтва, про найбільш видатних учених [27] (рис. 4).

Biageaphy O N L I N E
People who changed the world - Famous people who changed the course of
history including Socrates, Newton, Jesus Christ, Muhammad, Queen Victoria,

\section{Pис. 4. Головна сторінка Biography Online}

Біографії на цьому ресурсі розміщено за такими галузями: працівник мистецтва, підприємець, гуманіст, письменник, військовий, музикант, поет, політика, королівська 
влада, учений, спорт, релігійний лідер. Категорія учені містить біографії за розділами: відомі вчені, учені 17-21 ст. (рис. 5).

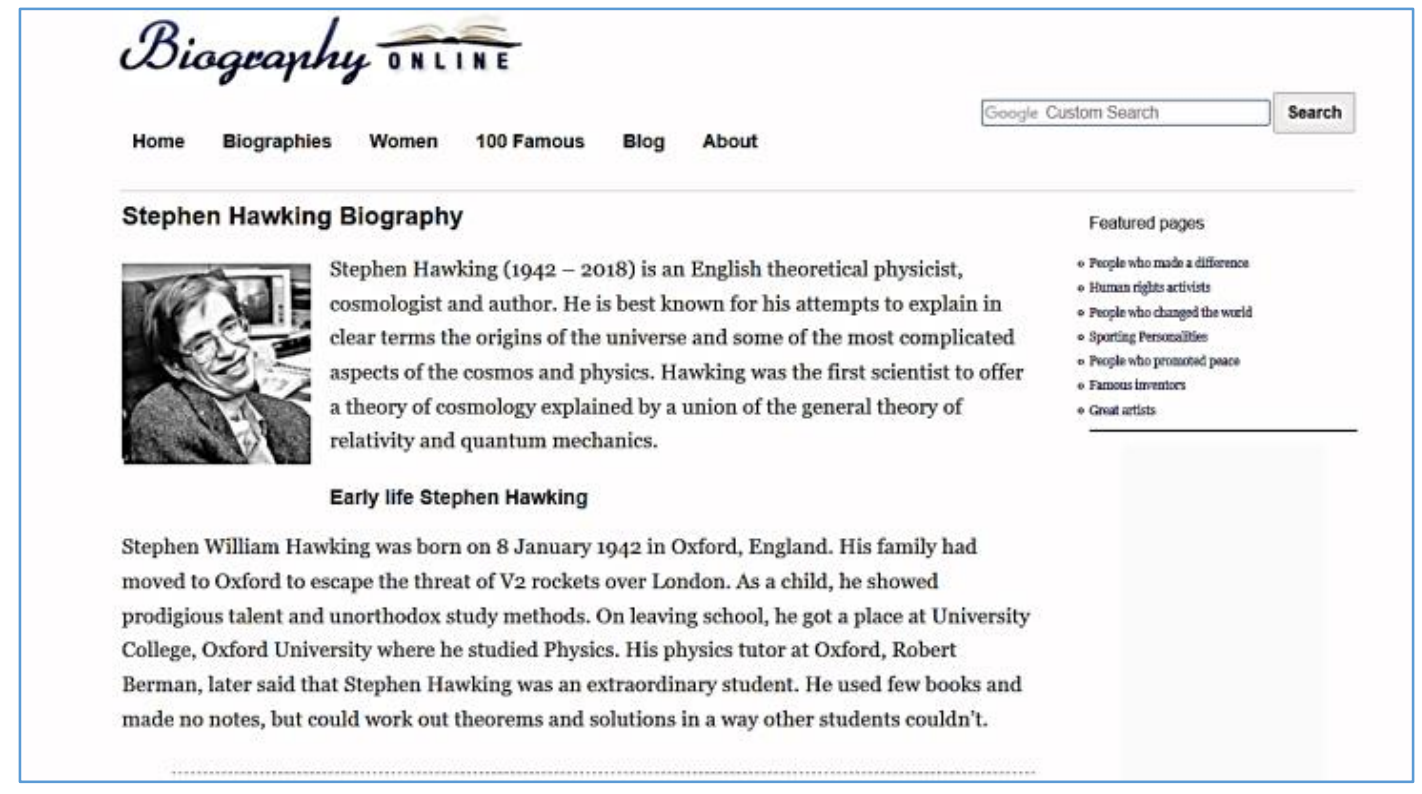

\section{Рис. 5. Біографія Стівена Хокінга на ресурсі Biography Online}

Енциклопедії, словники, атлас і декілька альманахів, які містять статистику, факти та історичні записи, ресурси всього довідкового інформаційного центру, розміщено на pecypci Infoplease [28]. Він призначений для батьків, учителів та бібліотекарів для отримання фактичної інформації з різних тем, зокрема актуальні події, поп-культура, наука, уряд та історія (рис. 6).

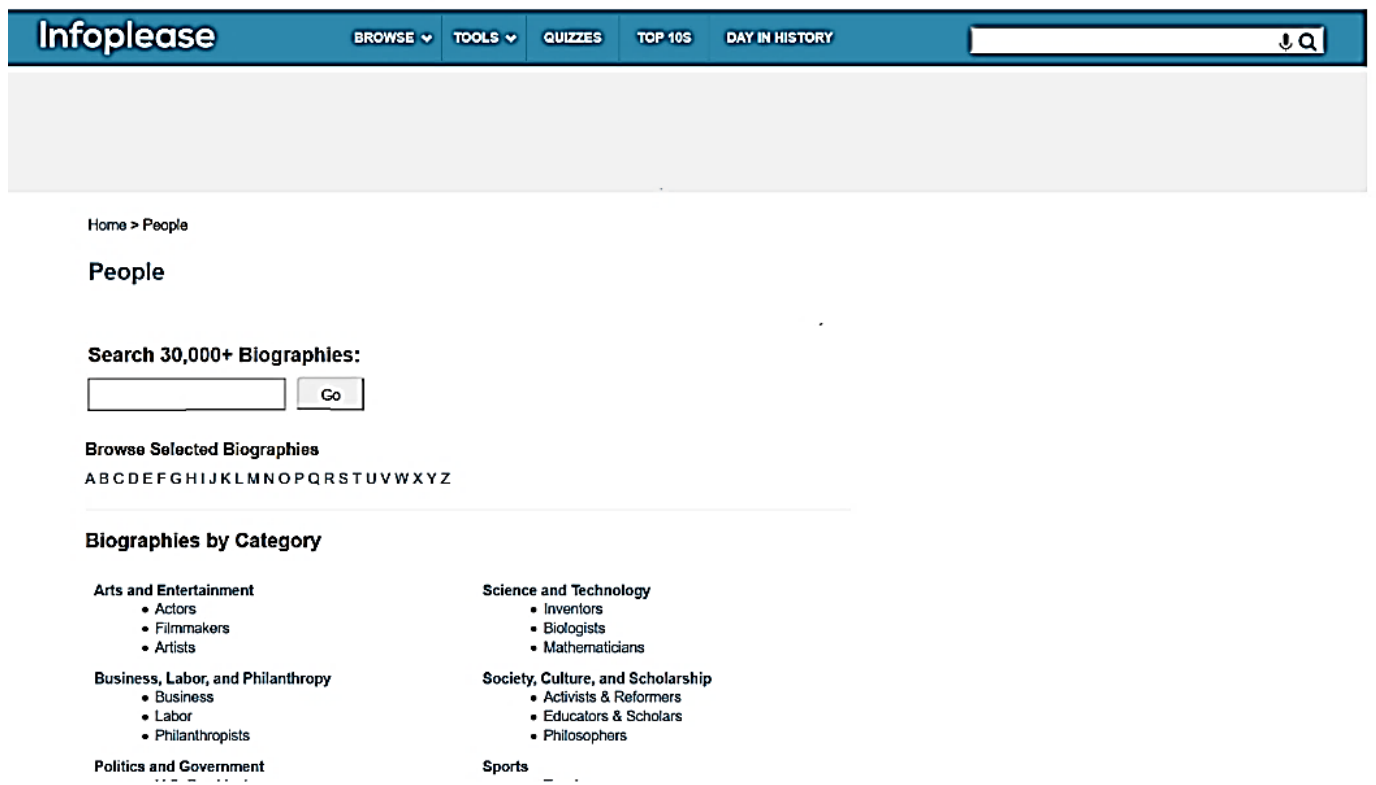

Рис. 6. Головна сторінка сайту Infoplease

У меню ресурсу в категорії «Люди» розміщено розділ «Наука», який містить біографії астронавтів і авіаторів, дослідників математики і статистики, учених у галузі прикладних наук і технологій, наук про Землю, наук про життя, фізичних наук, про 
афро-американських учених і винахідників, азіатсько-тихоокеанських американських і латиноамериканських учених, жінок-учених тощо.

У меню категорії «Суспільство, культура та гуманітарна освіта» здійснено персоналізацію педагогів та вчених з гіперпосиланням на їх біографію (рис. 7).

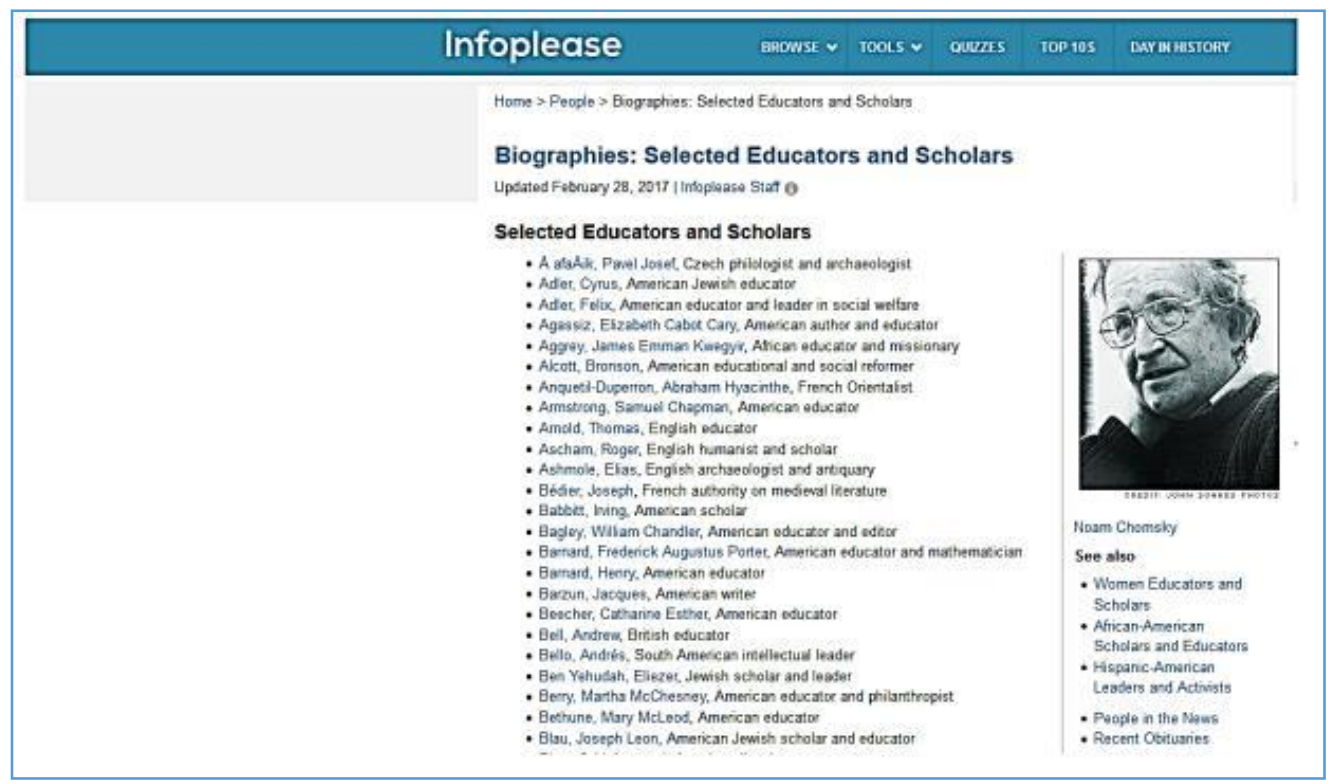

Pис. 7. Категорія «Видатні педагоги та вчені» на сайті Infoplease

Компанією Ahlul Bayt DILP створено найбільшу у світі цифрову ісламську бібліотеку в Інтернеті [29]. На ресурсі, окрім біографій, здійснено порівняльне дослідження загальних поглядів мусульманських i немусульманських учених на філософію й освіту (рис. 8).

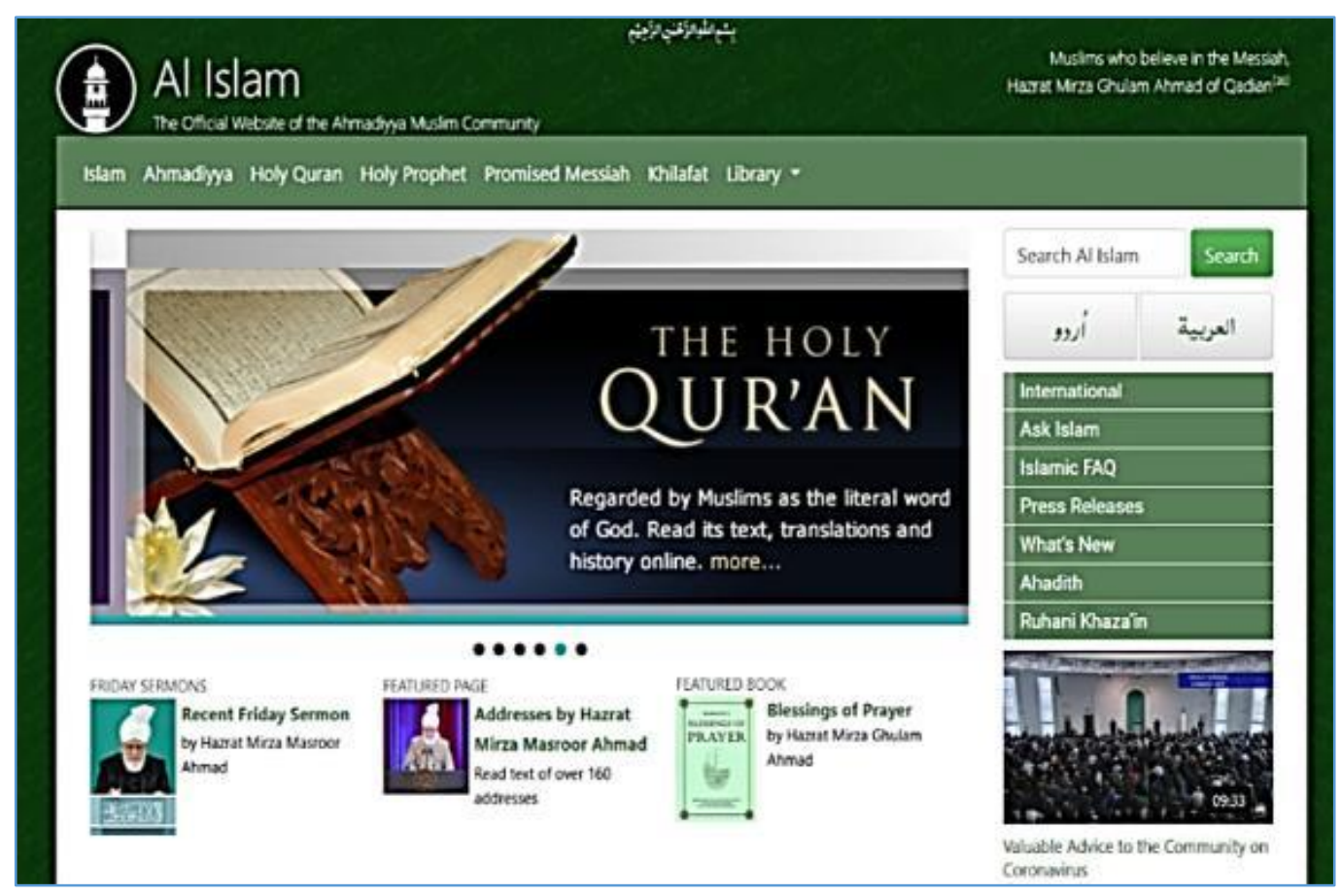

Pис. 8. Головна сторінка сайту Al-islam.org 
На сайті The famous people у категорії «пропагандисти» розміщено список відомих педагогів з їх біографіями, у яких зазначена незначна інформація, цікаві факти, дати та життєві події [30]. Тут можна здійснити вибір потрібних осіб за професією, національністю, статтю, днем народження тощо (рис. 9).

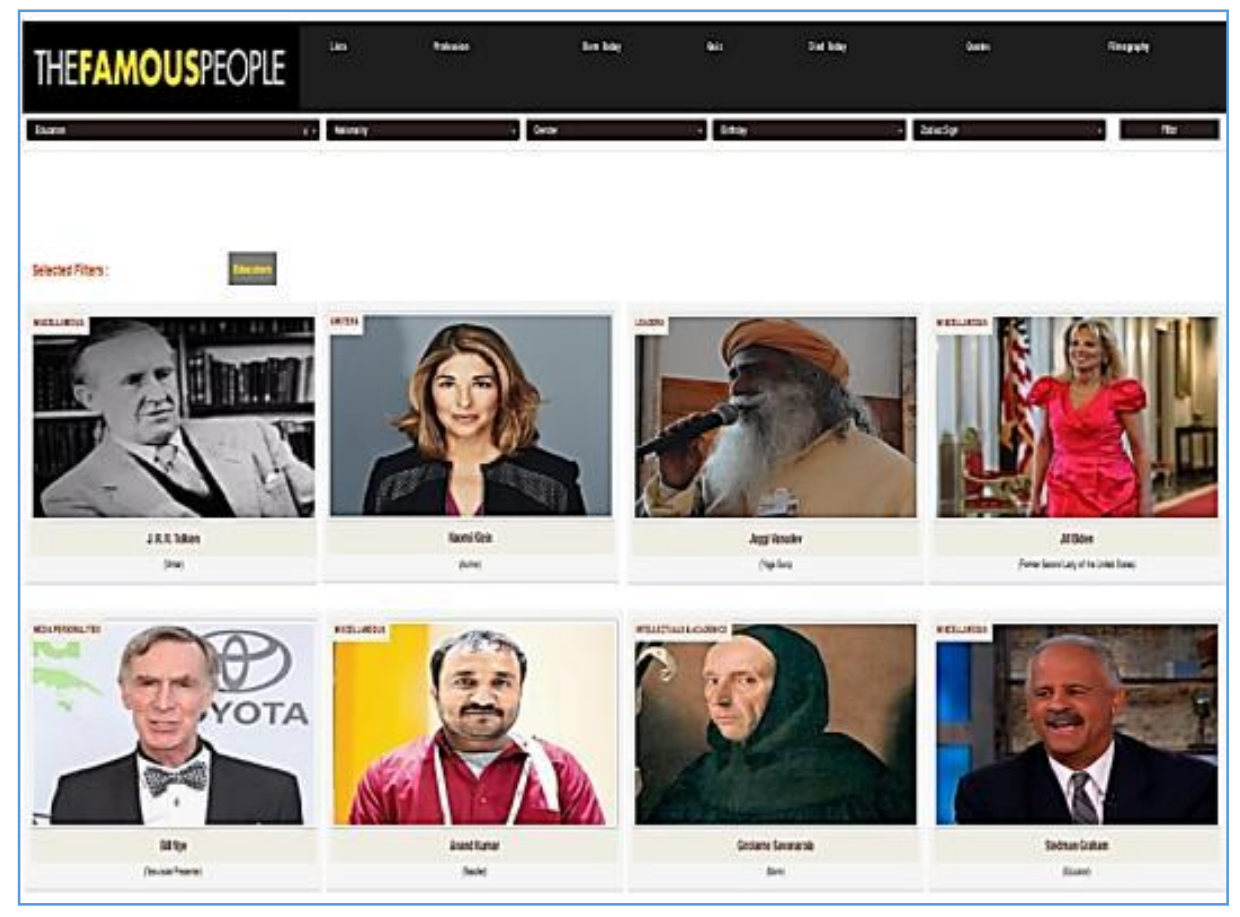

Puc. 9. Caüm The famous people: neдагоги

Узагальнення досвіду створення світових інформаційних та інформаційноосвітніх ресурсів дозволяє зробити висновок, що в багатьох країнах розроблена потужна система бібліографістики, яка функціонує в умовах сучасного динамічного середовища та забезпечує високий рівень якості розширення світогляду людей i здобуття доступної загальної середньої та вищої професійної освіти.

Недостатньо з'ясованим, тому невиразним у науково-інформативному полі української історико-педагогічної науки, залишається статус пам'ятних календарів, які видаються в книжковому або статейному форматах та розглядаються як різновид навчально-методичного забезпечення, біобібліографії тощо. За будь-яких підходів вони сприяють розвиткові педагогічної біографістики та мають попит у науковопедагогічних працівників, учителів, просвітян, студентів тощо.

Таким прикладом слугує започаткований у 2002 р. Державною науковопедагогічною бібліотекою України ім. В.О.Сухомлинського у форматі бібліографічного посібника «Календар знаменних і пам'ятних дат у галузі освіти i педагогічної науки». Його щорічні випуски мають усталену структуру: у розділах «Визначні дати року», «Визначні й пам'ятні дати за місяцями», «Науковці НАПН України - ювіляри 20** року» тощо в хронологічному порядку подається інформація про важливі події розвитку української і зарубіжної освіти та педагогічної думки; біографічні нариси про видатних педагогів, освітян, громадських діячів, учителівноваторів та ін.

Про значний науковий і навчально-пізнавальний ресурс цього календаря свідчить, до прикладу, випуск на 2018 р., який містить дані про близько 570 подій і пам'ятних дат, 3 них понад 340 присвячено персоналіям. Використанню такого обсягу інформації сприяє допоміжний апарат, що складається з іменного покажчика, списків скорочень i 
використаної літератури. Наукову і навчально-методичну цінність має бібліографічна частина, де анонсуються нові педагогічні й освітянські видання.

За результатами предметно-пошукової роботи було виявлено, що за період 2008 2009 рр. активізувалась практика підготовки і представлення бібліотечними установами календарів знаменних і пам'ятних дат на сайтах Інтернету. Зберігаючи властивий цим виданням формат, вони мають різну змістову спрямованість. Так, календарі Національної бібліотеки України ім. Ярослава Мудрого, публічної бібліотеки ім. Лесі Українки м. Києва в традиційному стилі, помісячно, фіксують дні народження відомих і ювілеї уродин менш знаних діячів історії, культури, освіти, а також знаменні події української історії і культури. Щільним, майже щоденним, форматом такої фіксації вирізняються календарі бібліотеки Вінницького державного педагогічного університету ім. Михайла Коцюбинського. Календарі різного рівня бібліотек i регіональних вишів, поряд із загальнонаціональними, фіксують пам'ятні дати і події, пов'язані 3 місцевими постатями і подіями. Чимало таких видань, як, наприклад, календар Івано-Франківської обласної бібліотеки для юнацтва, мають виразну навчально-методичну спрямованість, що обумовлено розміщенням матеріалів $\mathrm{i}$ рекомендацій для влаштування виховних заходів з ушанування пам'яті знаних діячів, використання їх творчості в навчальному процесі. Такий доволі ефективний для персоніфікації освітнього процесу підхід заслуговує на поширення в освітніх закладах різного типу.

Інше змістове наповнення мають неперіодичні календарі знаменних і пам'ятних дат Кам'янець-Подільського державного університету, які у вигляді статей подають інформацію про діяльність вишу та ювілеї його працівників у жанрі бібліографічних нарисів [31]. Такі видання розглядаємо як ще одне нове явище в розвитку педагогічної біографістики України.

Значним сучасним ресурсом $є$ «база даних «Науковці Хмельниччини» краєзнавчий інформаційний ресурс, який максимально повно розкриває життєвий шлях та наукову діяльність учених, що мають звання «доктор наук», «професор». Персональні рубрики розміщені за абеткою прізвищ і містять коротку біографічну довідку, список наукових праць та список літератури про діяча (Рис.10).

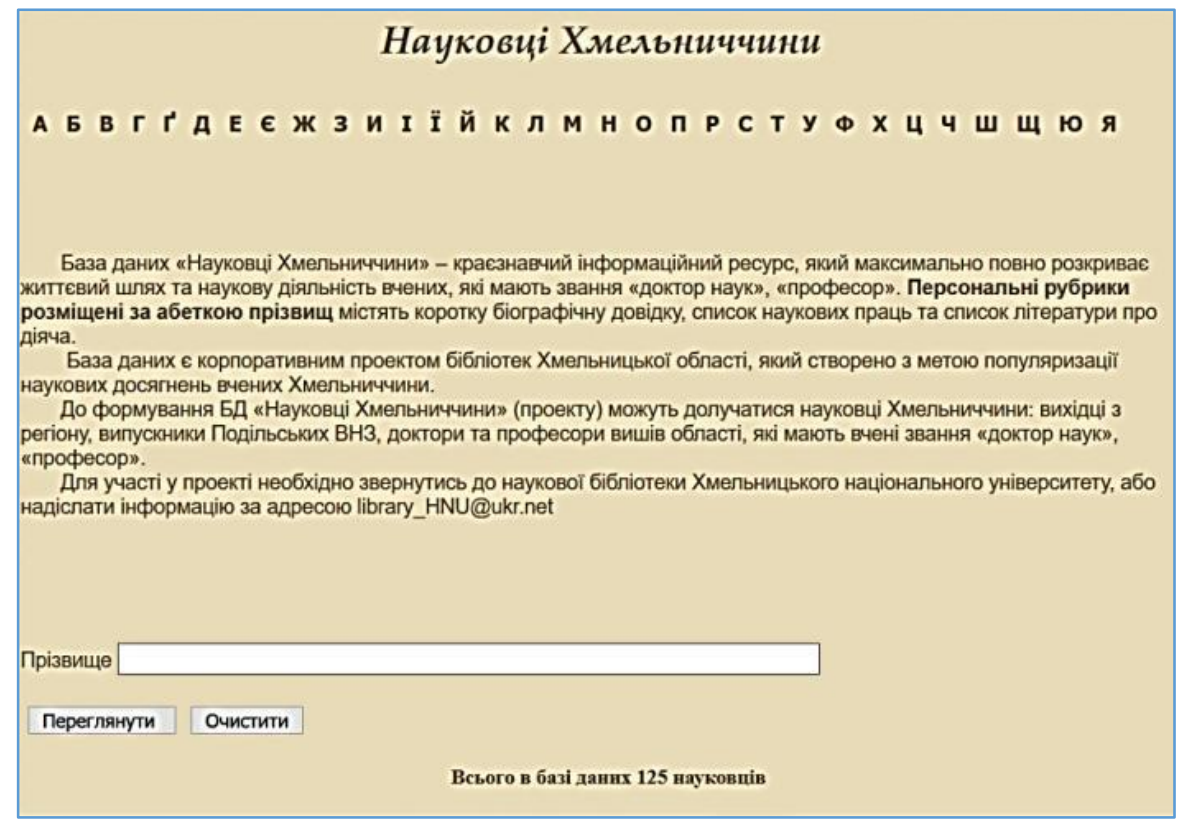

Рис. 10. База даних «Науковиі Хмельниччини» (головна сторінка) 
База даних є корпоративним проєктом бібліотек Хмельницької області, який створено з метою популяризації наукових досягнень учених Хмельниччини.

До формування БД «Науковці Хмельниччини» (проєкту) долучаються науковці Хмельниччини: вихідці з регіону, випускники Подільських ЗВО, доктори та професори вишів області, які мають вчені звання «доктор наук», «професор».

Розмаїття підходів, трактувань, формату презентації, інших аспектів персоналізації історії розвитку освіти і педагогічної думки в Україні відображають підручники і навчальні посібники з історії педагогіки. Після ознайомлення з двома десятками таких видань для предметного аналізу в означеному контексті були відібрані праці Л. Артемової [32], I. Зайченка [33], О. Любара [34], [35], М. Стельмаховича [34] і навчальні видання за редакцією О. Дубасенюк, В. Кременя [2], [3], Г. Троцко [36] тощо. Попри відмінності в структурно-змістовому наповненні, вони відображають спільну тенденцію, коли з відновленням державного суверенітету України в 90-х рp. XX ст. активізувався пошук нових підходів до висвітлення історії розвитку національної освіти й педагогічної думки. Важливим засобом утвердження національно орієнтованої парадигми стала персоніфікація цього процесу, що стала щільнішою в проєкції наближення до сучасності. Поступово окреслився неформальний пантеон знакових постатей, що персоніфікують окремі періоди: Польсько-Литовський XIV - XV ст. (П. Русин, Ю. Дрогобич та ін.); національного відродження XVI - XVIII ст. (Г. Сковорода, О. Духнович та ін.); імперський XIX - початку XX ст. (Т. Шевченко, М. Костомаров, П. Куліш, М. Пирогов, К. Ушинський, М. Драгоманов, Б. Грінченко, І. Франко, Леся Українка та ін.); добу УНР (І. Огієнко, М. Грушевський, С. Русова, Г. Ващенко та ін.); період 20 - 30-х pp. ХХ ст., 3 якого в окремих виданнях [32], Троцко Г. [36] «випадають» західноукраїнські землі (А. Макаренко, П. Блонський, С. Шацький, Я. Чепіга, А. Мамонтов, О. Залужний, О. Музиченко, Т. Лубенець, I. Соколянський та ін.); радянський період 50-80-х pp. XX ст. (О. Сухомлинський та ін.).

Формат презентації персоналії обирався залежно від іiі ролі та впливу на розвиток освіти й педагогічної думки. Як правило, найбільш повно розкриваються життєвий шлях та напрями, зміст професійної, творчої і громадської діяльності найбільш значущих постатей 3 акцентом на доведення новизни і значущості їх ідей та практичного досвіду. Намагання охопити якнайширше коло діячів i розкрити їх творчість нерідко призводило до описового стилю подачі матеріалу у вигляді розташованих у хронологічному порядку нарисів. До прикладу, у книзі за редакцією О. Любара розділ «Національна школа і педагогіка в Українській Народній Республіці» фактично подається через призму життєдіяльності I. Стешенка, I. Огієнка, М. Грушевського [34, с. 301-316]. Вважаємо, що такий підхід призводить до нівелювання загального історико-педагогічного контексту розвитку освіти i педагогічної думки.

Можемо констатувати, що на початку XXI ст. науковці представили загальний літопис тисячолітнього розвитку української педагогічної думки. Одним із виявів цього $\epsilon$ фундаментальна праця I. Зайченка, яка презентує творчу спадщину й освітню діяльність кількох сотень педагогічних персоналій [32]. Нагромадження фактологічних і теоретичних матеріалів актуалізує потребу синтезу та зіставлення педагогічних ідей та біографій, зокрема на рівні створення колективних портретів, які б презентували освітньо-педагогічні феномени окремих періодів та генерацій педагогів і просвітян.

Як один із таких прикладів відзначимо підготовлені за редакцією О. Сухомлинської «Нариси історії українського шкільництва. 1905-1933». Через призму громадсько-педагогічного руху за національну освіту кінця XIX - початку XX ст. та боротьби за українську школу за доби визвольних змагань $1917-1920$ рp. i утвердження радянського режиму в 1920 - 1933 рр. у праці представлені життєписи 
С. Русової, Бориса i Марії Грінченків, С. Черкасенка, Г. Гринька, О. Шумського, Я. Ряппо, М. Скрипника, О. Залужного, Я. Чепіги, І. Соколянського, О. Музиченка, Т. Лубенця [16], які достатньо цілісно відображають розвиток педагогічної науки й освіти означеного періоду.

Нагромаджена в різних галузях знань емпірична база біографічної інформації стимулює створення колективних біографій представників окремих освітньопедагогічних осередків не лише за сучасних умов, а й в історичній ретроспективі. 3 огляду на це ватро відзначити працю В. Микитася «Давньоукраїнські студенти i професори» (1994) [37], у якій у контексті висвітлення наукової і просвітницької діяльності українських гуманістів, діячів Острозької школи-колегіуму, КиєвоМогилянської академії, функціонування різного роду об'єднань інтелектуалів тощо подаються розгорнуті біографічні характеристики.

Аналіз історіографії педагогічної біографістики в хронологічному, регіональному, інших вимірах підтвердив активний розвиток персоніфікованих напрямів історикопедагогічної науки (ушинськознавство, пироговознавство, макаренкознавство, сухомлиністика, русознавсто, ващенкознавство); поступовий вихід за межі найпопулярнішого періоду історико-біографічних студій другої половини XIX - першої половини XX ст. (на нього припадає до 75-80 \% усіх праць) в історичній ретроспективі та перспективі (вивчення педагогічних персоналій XII - XVIII ст. та радянського і сучасного періодів).

За сучасних умов увиразнилася така особлива риса педагогічної біографістики, як вивчення в іï предметному полі широкого кола діячів, які представляють різні галузі знань і сфери суспільного життя (література, філософія, історія, мистецтво, етнографія, медицина, економіка; вчені-енциклопедисти, державні, церковні, військові діячі тощо). Використання міждисциплінарного, структурно-типологічного, феноменологічного підходів дозволило з'ясувати та інтерпретувати у розрізі історико-педагогічної науки світоглядні, наукові, професійні, громадські аспекти їх життєдіяльності.

Узагальнюючи наукові розвідки щодо особливостей створення цифрової інфраструктури як інноваційного формату персоніфікації історії освіти і педагогічної думки в Україні, зазначимо, що єдиної мережі вебресурсів і технологій їх функціонування поки ще не створено, відповідно, не розроблено комплексу науковометодичного супроводу їх функціонування. Проте в українській педагогічній науці обгрунтовані методологічні підходи до визначення історичних періодів розвитку освіти, наукових шкіл, які стали провідними в різні періоди, вивчення біографій i наукового доробку персоналій - засновників цих шкіл. На сучасному етапі розвитку педагогічної науки і освіти в Україні виявляється тенденція посилення застосування цифрових технологій, що створює передумови для переходу до інноваційного формату висвітлення персоніфікації історії освіти і педагогічної думки.

На цьому етапі дослідження на основі міждисциплінарного контексту ми пропонуємо наступну сукупність об'єктів (статей), що можуть бути представлені в цифровій інфраструктурі як інноваційний формат персоніфікації історії освіти і педагогічної думки в Україні: біографія відомих педагогів, лідерів педагогічної думки; ідеї, що зумовили новий напрям розвитку педагогіки й освітньої практики; авторські педагогічні й управлінські системи; наукові праці, концепції, теоретичні здобутки; оригінальні підручники, методики і методичні розробки педагогів, створені ними дидактичні і технічні засоби навчання.

Цифрова інфраструктура як інноваційний формат персоніфікації історії освіти i педагогічної думки в Україні вбачається комплексом вебпослуг, призначених для створення, зберігання та використовування впорядкованих в алфавітному порядку інтегрованих статей персоніфікації історії освіти й педагогічної думки в Україні, які 
пов'язані між собою гіперпосиланнями для переходу 3 однієї статті в іншу. Передбачається, що ресурс матиме вебінструментарій високошвидкісного пошуку необхідного матеріалу за ключовими словами 3 доступністю широкому колу користувачів.

\section{4. ВИСНОВКИ ТА ПЕРСПЕКТИВИ ПОДАЛЫШИХ ДОСЛІДЖЕНЬ}

Реалії сучасного оновленого суспільства, виокремлюючи персоніфікацію історії освіти і педагогічної думки в Україні як галузь, потребують розглядати цифровізацію як інструмент іï розвитку. За умови їх системного використання буде значно стимулюватися розвиток динамічного інформаційного бібліографічного ресурсу як одного з істотних факторів розвитку персоніфікації історії освіти й педагогічної думки в Україні. Цифровізація цієї галузі в Україні спричинятиме та вмотивовуватиме появу нових форм партнерства і співробітництва дослідників персоналій. На підставі проаналізованих у статті ресурсів та їх специфіки вирізнилася потреба їх створення у форматі структурованих цифрових просторів (вебпросторів), які мають бути відкритими для розгалуження, доповнення та коригування користувачами (за умови їх розширеної авторизації).

У перспективі розвиток галузі персоніфікації історії освіти й педагогічної думки в Україні завдяки цифровим технологіям відкриє можливість переміщення велетенськими кроками 3 традиційного й застарілого середовища до сучасних або надсучасних систем - цифрових інфраструктур.

\section{СПИСОК ВИКОРИСТАНИХ ДЖЕРЕЛ}

[1] С. У. Гончаренко, «Методологія», Енџиклопедія освіти. гол. ред. В.Г. Кремінь. Київ: Юрінком Інтер, с. 498-599, 2008.

[2] С. У. Гончаренко, «Наукові школи в педагогіці». Становлення і розвиток наук.-педагог. шкіл: проблеми, досвід, перспективи: зб. наук. праць. за ред. В. Кременя, Т. Левовицького. Житомир: Вид-во ЖДУ ім. І. Франка, с. 27-43, 2012.

[3] С. У. Гончаренко, «Педагогічна наука». Енцииклопедія освіти . Акад. пед. наук України; головний ред. В.Г. Кремень. Київ: Юрінком Інтер, с. 646-647, 2008.

[4] С. У. Гончаренко Украӥнський педагогічний словник; [гол. ред. С. Головко]. Київ: Либідь, 1997, 373 c.

[5] О.В. Сухомлинська, «Переднє слово». Українська педагогіка в персоналіях: у 2 кн. Кн. перша. ХХІХ століття. за ред. О.В. Сухомлинської. Київ: Либідь, с. 3-8, 2005.

[6] Т.М. Усатенко, «Українознавчі проблеми педагогічної думки в XIX XX столітті», автореф. дис. док. пед. наук. Київ, 2007, 42 с.

[7] I. Стражнікова, «Проблеми вивчення персоналізму в сучасних історико-педагогічних дослідженнях», Освітній простір. Глобальні, регіональні а інформаційні аспекти: науковометодичний журнал. Чернівці: Черемош, с. 41 - 44, 2010.

[8] М.С. Петрова, Просопография как специальная историческая дисииплина (на примере авторов Позднейантичности Макробия Феодосия и Марциана Капеллы). Санкт-Петербург: Алетейя, 2004, $254 \mathrm{c}$.

[9] И.Ф. Петровская, Биографика. Введение в науку и обозрение источников биографических сведений о деятелях России, 1801-1917 г2. Санкт-Петербург: Logos, 2003, 490 с.

[10] I. Старовойтенко, «Просопографія: підходи до трактування змісту наукової дисципліни в історіографії», Спеціальні історичні дисцииліни: питанння теорії та методики, с. 6- 27, 2006.

[11] Ю.Ю. Юмашева, Проблемы просопографии [Електронний ресурс]. Доступно: aiksng.ru/text/bullet/12/45-51.pdf. Дата звернення:Берез.15, 2020.

[12] В.С. Курило, «Становлення і розвиток системи освіти та педагогічної думки Східноукраїнського регіону в ХХ столітті», дис. док. пед. наук, Луганськ, 2000, 507 с.

[13] I.I. Корнєйчик Історія української бібліографї: нариси. Харків: Ред.-вид. відділ Книжк. палати УРСР, 1971, $174 \mathrm{c}$. 
[14] В.О. Сухомлинский.: библиогр. сост. А.И. Сухомлинская, О.В. Сухомлинская. Київ: Радян. шк., $1987,256 \mathrm{c}$.

[15] 22 видатних українських педагоги: персоналії в історії наџіональної педагогіки : підруч. для студ. Вузів. А.М. Бойко, В.Д. Бардінова, Л.Л. Безобразова [та ін.]; під заг. ред. А. М. Бойко.Київ : Професіонал, 2004, 576 с.

[16] Нариси з історії розвитку педагогічної думки : навч. посібник для студ. вищу. навч. закладів . С. О. Сисоєва, І. В. Соколова. Київ : ЦУЛ, 2003, 308c.

[17] Видатні украйнські педагоги: інформаційний довідник. [авт.-упоряд. Л. В. Калуська]. Тернопіль : Мандрівець, 2008, 224 с.

[18] Герої-освітяни і науковці України . Нац. акад. пед. наук України, Ін-т педагогіки НАПН України, Київ. нац. ун-т ім. Тараса Шевченка ; [упоряд.: О. А. Сай та ін.]. 2-ге вид., допов. Київ: Генеза, 2012, 462 c.

[19] Best Sellers in Biographies of Educators, 2020. [Електронний ресурс]. Доступно: https://www.amazon.com/Best-Sellers-Kindle-Store-Biographies-Educators/zgbs/digitaltext/154797011/ref=zg_bs_nav_kstore_5_154803011. Дата звернення: Травень 02, 2020.

[20] O. Iefremova, K. Wais \& Kozak, M. «Biographical articles in scientific literature: analysis of articles indexed in Web of Science», Scientometrics, 117, p. 1695-1719. 2018. [Електронний ресурс]. Доступно: https://doi.org/10.1007/s11192-018-2923-3. Дата звернення: Липень 16, 2020.

[21] Adam Langley, Dan S. Bloomberg, 2007. «Google Books: Making the public domain universally accessible», Proceedings of SPIE. [Електронний pecypc]. Доступно: https://www.imperialviolet.org/binary/google-books-pdf.pdf. Дата звернення: Червень 01, 2020.

[22] Leetaru, K. (2008). Mass book digitization: The deeper story of Google Books and the Open Content Alliance. First Monday, 13(10). doi:https://doi.org/10.5210/fm.v13i10.2101.

[23] B. Morsello, «Digitalization of life. How technology redefine the self in the global context», Easst Review, 35, 4, pp. 94-97, 2016. [Електронний ресурс]. Доступно: https://easst.net/article/digitalizationof-life-how-technology-redefine-the-self-in-the-global-context/. Дата звернення: Травень 24, 2020.

[24] The most recommended books on business, technology and science. [Електронний ресурс]. Доступно: https://bookauthority.org/. Дата звернення: Липень 15, 2020.

[25] New World Encyclopedia. [Електронний pecypc]. Доступно:. http://www.newworldencyclopedia.org/ entry/ Category:Biography. Дата звернення: Липень 03, 2020.

[26] National Biography of Finland. [Електронний ресурс]. Доступно: https://kansallisbiografia.fi/english. Дата звернення: Травень 19, 2020.

[27] Biography on line, 2020. [Електронний ресурс]. Доступно: https://Www.Biographyonline.Net/People.Html. Дата звернення: Травень 14, 2020.

[28] Infoplease. [Електронний ресурс]. Доступно: https://www.infoplease.com/. Дата звернення: Травень 29, 2020.

[29] Al-islam, 2020. [Електронний ресурс]. Доступно: https://www.al-islam.org/tags/education. Accessed on: May 21, 2020.

[30] The famous people. [Електронний pecypc]. Доступно: https://www.thefamouspeople.com/ educators.php. Дата звернення: Травень 03, 2020.

[31] Науковиі Хмельниччини. [Електронний ресурс]. Доступно: http://lib.khnu.km.ua/asp/php_bibliograf_ php/page_lib.php. Дата звернення:Черв.10, 2020.

[32] Л. В. Артемова, Історія педагогіки України : підруч. Київ: Либідь, 2006. 420 с.

[33] І.В. Зайченко, «Іторія педагогіки» у 2 кн. Кн. II. Школа, освіта і педагогічна думка в Україні: навч. посіб. Київ: Вид. Дім «Слово», 2010, 1032 с.

[34] О.О. Любар, Історія украӥнської школи і педагогіки: навч. посіб. за ред. О.О. Любара, М.Г. Стельмаховича, Д.Т. Федоренка. Київ: Знання КОО, 2003, 450 с.

[35] О.О. Любар, Д.Т. Федоренко, Історія педагогічної думки і освіти в Украӥні. Ч. 1. Київ, 1993,448 с.

[36] Історія педагогіки . за заг. ред. Г. В. Троцко. Харків: ХНПУ, 2008, 545 с.

[37] В.Л. Микитась, О.В. Духнович, Літературно-критичний нарис. Ужгород: Закарпатське обл. видво, 1959, 101 c. 


\title{
ОРГАНИЗАЦИОННЫЕ ОСНОВЫ ФОРМИРОВАНИЯ ЦИФРОВОЙ ИНФРАСТРУКТУРЫ ОБРАЗОВАНИЯ И ПЕДАГОГИЧЕСКОЙ НАУКИ В УКРАИНЕ (КОНЕЦ 80-Х ГГ. ХХ ВЕКА-НАЧАЛО ХХІ ВЕКА)
}

\author{
Гуржий Андрей Николаевич \\ доктор технических наук, профессор, академик НАПН Украины \\ НАПН Украины, г. Киев, Украина \\ ORCID ID 0000-0002-2797-5831 \\ gurzhij.andrij@gmail.com
}

\section{Бахмат Наталья Валерьевна}

доктор педагогических наук, профессор, профессор кафедры теории и методики начального образования Каменец-Подольский национальный университет имени Ивана Огиенко, г. Каменец-Подольский, Украина ORCID ID 0000-0001-6248-8468

bahger.teacher@gmail.com

\section{Зайчук Валентин Александрович}

кандидат педагогических наук, профессор, академик НАПН Украины

НАПН Украины, м. Киев, Украина

ORCID ID 0000-0002-8895-1569

zaichuk@narada.gov.ua

\section{Карташова Любовь Андреевна}

доктор педагогических наук, профессор, заместитель директора по дистанционному обучению Центральный институт последипломного образования УМО НАПН Украины, г. Киев, Украина ORCID ID 0000-0002-1270-4158

lkartashova@ua.fm

\section{Розман Ирина Ильинична}

кандидат педагогических наук, доцент, кафедры филологии и социальных коммуникаций

Мукачевский государственный университет, г. Мукачево, Украина

ORCID ID 0000-0002-4951-0074

rozmanii@ukr.net

\section{Сорочан Тамара Михайловна}

доктор педагогических наук, профессор, профессор кафедры философии и образования взрослых Университет менеджмента образования НАПН Украины, г. Киев, Украина

ORCID ID 0000-0002-4704-2385

anprof@ukr.net

\begin{abstract}
Аннотация. В статье рассмотрены предпосылки, динамика, тенденции, институциональная база развития современной педагогической биографии в Украине. Подчеркнуто, что конец 80$\mathrm{x}$ годов XX в. - начало XXI в. является основой для содержательного осмысления ее историографии. Акцентировано внимание на накопленной историографии значительных объемов различных исходных материалов. Установлено, что по результатам аналитического обзора они делятся на три категории, охватывающие работу, в которой осуществляется олицетворение развития украинской педагогической мысли и изучения педагогического коллектива Украины и за рубежом. Это доказывает потребность в тщательном изучении жизни и достижений незаурядных фигур, которые определяют лицо образования и педагогики недавнего прошлого.

Установлено, что библиография как соответствующий отраслевой ресурс является поисковой инфраструктурой. Выявлено, что необходимо учитывать использование цифровой библиографии, приведены примеры цифровых ресурсов как мощных инструментов для быстрого поиска биографий известных педагогов и ученых. Это подтверждает наличие разработанной сильной системы библиографистики в зарубежных странах, функционирующей в условиях современной динамической среды и обеспечивающей высокий уровень качества расширения кругозора людей и получение доступного общего среднего и высшего профессионального образования в целом.
\end{abstract}


Исследования показали, что прогнозируется преобразование персонификации истории образования и педагогической мысли в Украине в цифровую инфраструктуру государственного и мирового уровня в соответствии с цифровизацией общества. Подчеркивается, что в конкретных педагогических исследованиях ученые, как правило, ограничиваются лишь кратким толкованием биографии в соответствии с предметом их исследования. Отмечено, что в процессе накопления массива научной, учебной, научнопопулярной, справочной литературы о жизнедеятельности педагогических персоналий в украинской историко-педагогической науке сформировалось отдельное междисциплинарное исследовательско-персонифицированное направление - педагогическая биографистика.

Ключевые слова: педагогическая мысль; педагогическая биографистика, просопография; пространственно-временной подход; идентификация; ресурс; информатизация; диджитализация.

\title{
ORGANIZATIONAL GROUNDS FOR DEVELOPMENT OF DIGITAL INFRASTRUCTURE OF EDUCATION AND PEDAGOGICAL SCIENCE IN UKRAINE (LATE 80S OF THE XX CENTURY-BEGINNING OF THE XXI CENTURY)
}

\author{
Andrii M. Hurzhii \\ Doctor of Technical Sciences, Professor, Academician of NAES of Ukraine \\ NAES of Ukraine, Kyiv, Ukraine \\ ORCID ID 0000-0002-2797-5831 \\ gurzhij.andrij@gmail.com
}

Nataliia V. Bakhmat

Doctor of Pedagogical Sciences, Professor, Professor at Elementary Education Theory and Methods Department Kamianets-Podilskyi National Ivan Ohiienko University, Kamyanets-Podilskyi, Ukraine

ORCID ID 0000-0001-6248-8468

bahger.teacher@gmail.com

Valentin O. Zaychuk

PhD of Pedagogical Sciences, Professor, Academician of NAES

NAES of Ukraine, Kyiv, Ukraine

ORCID ID 0000-0002-8895-1569

zaichuk@narada.gov.ua

\section{Lyubov A. Kartashova}

Doctor of Pedagogical Sciences, Professor, Deputy Director of Distance Learning

Central Institute of Postgraduate Education of UEM NAES of Ukraine, Kyiv, Ukraine

ORCID ID 0000-0002-1270-4158

lkartashova@ua.fm

Iryna I. Rozman

$\mathrm{PhD}$ of Pedagogical Sciences, Associate Professor

Mukachevo State University, Mukachevo, Ukraine

ORCID ID 0000-0002-4951-0074

rozmanii@ukr.net

\section{Tamara M. Sorochan}

Doctor of Pedagogical Sciences, Professor, Professor at Department for Philosophy and Education of Adults University of Educational Management, NAES of Ukraine, Kyiv, Ukraine

ORCID ID 0000-0002-4704-2385

anprof@ukr.net

\begin{abstract}
The article considers the preconditions, dynamics, trends, institutional basis for the development of modern pedagogical biography in Ukraine. It is emphasized that the late 80's of XX early XXI century is the basis for meaningful understanding of its historiography. Emphasis is placed on the accumulated historiography of significant volumes of various source materials. It is established that according to the results of the analytical review they are divided into three categories, covering the
\end{abstract}


work for the development of Ukrainian pedagogical thought and the study of the teaching staff in Ukraine and abroad. This proves the need for a careful study of the life and achievements of outstanding figures who define the face of education and pedagogy of the recent past.

It is established that the bibliography, as a relevant industry resource, is a searching infrastructure. It is found that it is necessary to take into account the use of digital bibliography; examples of digital resources as powerful tools for quick search of biographies of famous teachers and scientists are given. This confirms the existence of a powerful bibliographic system developed in foreign countries, which operates in a modern dynamic environment and provides a high level of quality to expand people's worldview and obtain affordable general secondary and higher professional education in general.

Research has shown that the transformation of the educational history and pedagogical thought personification in Ukraine into a digital infrastructure of the state and world level is projected in accordance with the digitalization of society. It is emphasized that in specific pedagogical research the scholars are usually limited to a brief interpretation of the biography in accordance with the subject of their study. It is noted that in the process of accumulation of an array of scientific, educational, popular science, reference literature on the life of teachers in the Ukrainian historical and pedagogical science formed a separate interdisciplinary research and personalized direction - a pedagogical biography.

Keywords: pedagogical thought; prosopography; spatial-temporal approach; identification; resource; informatization; digitalization.

\section{REFERENCES (TRANSLATED AND TRANSLITERATED)}

[1] S.U. Goncharenko, "Methodology", Encyclopedia of Education, Kyiv: Yurinkom Inter, pp. 498-599, 2008. (in Ukrainian)

[2] S.U. Goncharenko, "Scientific schools in pedagogy", Formation and development of scientific pedagogical schools: problems, experience, prospects: Coll. Science. Works, Zhytomyr: ZhSU Publishing House. I. Franko, pp. 27- 43, 2012. (in Ukrainian)

[3] S.U. Goncharenko, "Pedagogical science", Encyclopedia of Education / Acad. ped. Sciences of Ukraine; editor in chief V.G. Flint. Kyiv: Yurinkom Inter, pp. 646-647, 2008. (in Ukrainian)

[4] S.U. Goncharenko, Ukrainian pedagogical dictionary; [Goal. ed. By S. Golovko]. Kyiv: Lybid, 1997, 373 p. (in Ukrainian)

[5] O.V. Sukhomlynska (Ed.), "Foreword”, Ukrainian pedagogy in personalities: in 2 books. Book the first. XXIX centuries. Kyiv: Lybid, pp. 3-8, 2005. (in Ukrainian)

[6] T.M. Usatenko, "Ukrainian studying problems of pedagogical thought in the XIX-XX century", author's ref. dis. Doc. ped. Sciences. Kyiv, 2007, 42 p. (in Ukrainian)

[7] I. Strazhnikova, "Problems of personals studying in modern historical and pedagogical research. Educational space", Global, regional and informational aspects: scientific and methodical magazine. Chernivtsi: Cheremosh, pp. 41 - 44, 2010. (in Ukrainian)

[8] M.S. Petrova, Prosopography as a special historical discipline (on the example of the authors of Late Antiquity Macrobius Theodosius and Marcian Capella). Saint-Petersburg: Aleteiya, 2004, 254 p.

[9] I.F. Petrovskaya, Biography. Introduction to science and review of sources of biographical information about Russian figures, 1801-1917. Saint-Petersburg: Logos, 2003, 490 p.

[10] I. Starovoitenko, "Prosopography: approaches to the interpretation of the content of the scientific discipline in historiography", in Special historical disciplines: questions of theory and methodology, pp. 6 - 27, 2006. (in Ukrainian)

[11] Yu.Yu. Yumasheva, Problems of prosopography. [Online]. Available: aik-sng.ru/text/bullet/12/4551.pdf. Accessed on: March 15, 2020.( in Russian)

[12] V.S. Kurilo, "Formation and development of the system of education and pedagogical thought of the East Ukrainian region in the twentieth century", dis. doc. ped. science, Luhansk, 2000, 507 p. (in Ukrainian)

[13] I.I. Korneychik, History of Ukrainian bibliography: essays. Kharkiv: Ed. Department of Books. Chamber of the USSR, 1971. 174 p. (in Ukrainian)

[14] V.O. Sukhomlinsky: bibliogr. Comp. A.I. Sukhomlinskaya, O. V. Sukhomlinskaya. Kiev: Radyan. shk., 1987,256 p. (in Ukrainian)

[15] A.M. Boyko, V.D. Bardinova, L.L. Bezobrazova et al., 22 outstanding mUkrainian teachers: personalities in the history of national pedagogy: textbook for universities students. Kyiv: Professional, 2004, 576 p. The famous people. [Online]. Available: https://www.thefamouspeople.com/ educators.php. Accessed on: May 03, 2020. (in Ukrainian)

[16] S.O. Sysoeva, and I.V. Sokolova, Essays on the history of pedagogical thought: textbook. manual for students. higher textbook institutions. Kyiv: CUL, 2003, 308p. (in Ukrainian) 
[17] L.V. Kaluska (Ed.), Outstanding Ukrainian teachers: information guide. Ternopil: Mandrivets, 2008,224 p. (in Ukrainian)

[18] Heroes-educators and scientists of Ukraine. Nat. acad. ped. Sciences of Ukraine, Institute of Pedagogy of the National Academy of Pedagogical Sciences of Ukraine, Kyiv. nat. Univ. Taras Shevchenko; [order .: OA Sai and others]. 2nd ed., add. Kyiv: Genesis, 2012, 462 p. (in Ukrainian)

[19] Best Sellers in Biographies of Educators, 2020 [Online]. Available: https://www.amazon.com/BestSellers-Kindle-Store-Biographies-Educators/zgbs/digital-text/154797011/ref=zg_bs_nav_kstore_5_ 154803011. Accessed on: May 02, 2020. (in English)

[20] O. Iefremova, K. Wais, and Kozak, "Biographical articles in scientific literature: analysis of articles indexed in Web of Science", Scientometrics, 117, pp. 1695-1719. 2018. [Online]. Available: https://doi.org/10.1007/s11192-018-2923-3. Accessed on: July 16, 2020. (in English)

[21] Adam Langley, Dan S. Bloomberg, 2007. «Google Books: Making the public domain universally accessible», Proceedings of SPIE. [Online]. Available: https://www.imperialviolet.org/binary/googlebooks-pdf.pdf. Accessed on: June 01, 2020. (in English)

[22] Leetaru, K. (2008). Mass book digitization: The deeper story of Google Books and the Open Content Alliance. First Monday, 13(10). doi:https://doi.org/10.5210/fm.v13i10.2101. (in English)

[23] B. Morsello, "Digitalization of life. How technology redefine the self in the global context», Easst Review, 35, 4, pp. 94-97, 2016. [Online]. Available: https://easst.net/article/digitalization-of-life-howtechnology-redefine-the-self-in-the-global-context/. Accessed on: May 24, 2020. (in English)

[24] The most recommended books on business, technology and science. [Online]. Available: https://bookauthority.org/. Accessed on: July 15, 2020. (in English)

[25] New World Encyclopedia. [Online]. Available:. http://www.new worldencyclopedia.org/ entry/ Category:Biography. Accessed on: July 03, 2020. (in English)

[26] National Biography of Finland. [Online]. Available: https://kansallisbiografia.fi/english. Accessed on: May 19, 2020. (in English)

[27] Biography on line, 2020. [Online]. Available: https://Www.Biographyonline. Net/People.Html. [Online]. Available: May 14, 2020. (in English)

[28] Infoplease. [Online]. Available: https://www.infoplease.com/. Accessed on: May 29, 2020. (in English)

[29] Al-islam, 2020. [Online]. Available: https://www.al-islam.org/tags/education. Accessed on: May 21, 2020. (in English)

[30] The famous people. [Online]. Available: https://www.thefamouspeople.com/ educators.php. Accessed on: May 03, 2020. (in English)

[31] Scientists of Khmelnytsky region. [Online]. Available: http://lib.khnu.km.ua/asp/php_ bibliograf_ php / page_ lib.php. Accessed on: June 10, 2020. (in Ukrainian)

[32] L.V. Artemova, History of pedagogy of Ukraine: textbook. Kyiv: Lybid, 2006, 420 p. (in Ukrainian)

[33] I.V. Zaichenko, "History of pedagogy": in 2 books. Book II. School, education and pedagogical thought in Ukraine: textbook. Kyiv: Ed. House "Word", 1032 p., 2010. (in Ukrainian)

[34] O.O. Lyubar, History of Ukrainian school and pedagogy: textbook. way. Kyiv: Znannia KOO, 2003, 450 p. (in Ukrainian)

[35] O.O. Lyubar, and D.T. Fedorenko, History of pedagogical thought and education in Ukraine. Part 1. Kyiv, 1993, 448 p. (in Ukrainian)

[36] History of pedagogy / for general. ed. GV Trotsky. Kharkiv: KhNPU, 2008, 545 p. (in Ukrainian)

[37] V.L. Mikitas, and O.B. Dukhnovych, Literary-critical essay. Uzhhorod: Transcarpathian region. type, 1959, 101 p. (in Ukrainian)

This work is licensed under Creative Commons Attribution-NonCommercial-ShareAlike 4.0 International License. 